\title{
Conservation of European ground squirrel (Mammalia: Rodentia) in Slovakia: Results of current reintroduction programme
}

\author{
Ochrana sysl’a pasienkového (Mammalia: Rodentia) na Slovensku: Výsledky aktuálneho \\ programu reštitúcie
}

\author{
Denisa LŐBBOVÁ \& Ervín HAPL
}

\begin{abstract}
Conservation of European ground squirrel (Spermophilus citellus) has been supported by the LIFE - Nature project "Conservation of Falco cherrug in NE Bulgaria, Hungary, Romania and Slovakia" during the period 2010-2014. The project activities were usually focused on EGS reintroduction programmmes with the aim of ensuring the food base for selected species of birds in areas where EGS were the primary historical prey and have become extinct. Reintroduction programmes were carried out at two sites in Slovakia: Piesočná (Moravský Svätý Ján) and Pod Okrúhlou skalou (Tisovec). Together 174 individuals were released at Pod Okrúhlou skalou and 284 individuals at the Piesočná target site. Monitoring of both repatriated colonies focused on the natality and distribution area. At both target sites successful hibernation and reproduction have been confirmed. The repatriation date was strongly influenced by weather conditions, especially during the rainy season. It was necessary to cut the grass several times per season, in order to ensure appropriate conditions for individuals' survival. It was also necessary to protect the individuals against predators. House cats tend to hunt squirrels, which can be considered as the most serious threat at the Piesočná site. Squirrels at the Pod Okrúhlou skalou site were overly attacked by foxes. Intensive care (especially appropriate management of sites and additional feeding) ensured good stability of colonies, their survival and increase.
\end{abstract}

\begin{abstract}
Abstrakt: V období rokov 2011 až 2014 bola ochrana sysl'a pasienkového (Spermophilus citellus) podporená projektom LIFE Nature „Ochrana sokola rároha v severovýchodnej časti Bulharska, Mad’arsku, Rumunsku a na Slovensku“. Projektové aktivity boli zamerané na prinavrátenie sysl'a na lokality s historickým výskytom s ciel'om zabezpečit’ prirodzenú potravnú bázu vybraných druhov dravcov. Reštitúcia bola realizovaná na dvoch lokalitách Slovenska: Piesočná (k. ú. Moravský Svätý Ján) a Pod Okrúhlou skalou (k. ú. Tisovec). Celkom bolo na lokalite Pod Okrúhlou skalou vypustených 174 jedincov a na lokalite Piesočná 284 jedincov. Ciel’om intenzívneho monitoringu oboch založených kolónií bolo zistit’ priebeh aklimatizácie jedincov na lokalitách - sledovanie distribúcie a rozmnožovania. Na oboch lokalitách bolo potvrdené úspešné prezimovanie a reprodukcia. Priebeh zakladania nových kolónií bol sprevádzaný daždivými sezónami. Bolo potrebné niekol'kokrát za sezónu kosit' lokality pre zaistenie vhodných podmienok k prežitiu jedincov. Rovnako potrebné bolo zaistit' ochranu jedincov pred predátormi. Najväčšiu hrozbu pre sysl’a na lokalite Piesočná predstavovali ataky túlavých mačiek, na lokalite Pod Okrúhlou skalou ataky líškami. Stabilitu, prežitie a nárast kolónií zabezpečí jedine intenzívna starostlivost' (vhodný manažment, prikrmovanie a pod.).
\end{abstract}

Key words: Spermophilus citellus, creating new colonies, monitoring, management, predators

Denisa Lőbbová, Ervín Hapl, Ochrana dravcov na Slovensku, Kuklovská 5, 84104 Bratislava, Slovakia. E-mail: goblin.denn@gmail.com, ervin.hapl@gmail.com.

Acknowledgements: This study and implementation of the reintroduction programme was supported by LIFE09 NAT/HU/000384 project "Conservation of Falco cherrug in NE Bulgaria, Hungary, Romania and Slovakia" 2010-2014. We would like to thank Raptor Protection of Slovakia for the opportunity to work on this project. We would also like to thank the field workers who participated in the EGS reintroduction programme: Dominika Csepányiová, Gabriela Benčuríková, Mária Jarošíková, Michal Ambros, Michal Šara, Peter Laboš, Romana Uhrínová and Tomáš Blaškovič. Special thanks go to the owners, stewards and farmers of the target sites - Mr. Tomek, Mr. Serbák, Mr. Komjaty and Mr. Novák. We would also like to thank Mr. Sekereš from Jesenské for his rich advice and exchange of experience regarding the establishment of a new EGS colony and ensuring its survival.

\section{Introduction}

Spermophilus citellus is a social animal that lives in colonies. The adults maintain small territories within larger home ranges. They inhabit a system of burrows which can be divided into escape burrows (temporary) and nesting burrows (permanent). Squirrels spend the winter in hibernation. The species plays an important role in steppe and cultural steppe ecosystems. On the 
one hand, it is part of the diet of carnivores and raptors, and on the other hand, females of several species of coprophagous beetles (Ontophagus vitulus, Ontophagus semicornis and Aphodius citellorum) lay eggs in soil with squirrel droppings, which serve as food for the larvae. Thus these beetles closely depend on the occurrence of European ground squirrel (EGS). Old squirrel burrows are used by other protected species such as Bufo viridis, Pelobates fuscus or Coronella austriaca. The EGS originally inhabited the steppe areas. During the postglacial era, it colonized its European range from a refuge on the Balkan Peninsula. Its spread was largely dependent on the expansion of farming that brought large-scale deforestation and replacement of forests with cultural steppe (pastures, meadows and fields). In the 1950s, in the former Czechoslovakia the inhabited species moved from meadows, pastures, fields of perennial fodder (such as clover or lucern), grassy margins of roads, balks and embankments, and currently most of the colonies could be found in regularly mowed areas with maintained short cover, such as airports, golf courses, and campsites (Uhlíková et al. 2009). Between 1996 and 2008 we detected the ground squirrel at 115 sites in Slovakia. Visits of sites with EGS occurrence, which were listed in older literature, showed that the majority of them $(87 \%)$ were altered and this protected species does not occur there anymore. Continuous survey with the application of monitoring elements to the observation of the EGS population shows that increased isolation of existing colonies has resulted in larger fragmentation of the species distribution in Slovakia. The situation is gradually getting into a state when immediate protection action is necessary (Ambros 2008).

Activities connected with EGS conservation in Slovakia were supported by the LIFE-Nature project "Conservation of Imperial Eagle in the Slovak Part of the Carpathian Basin" during the period 2003-2007, by the LIFE-Nature project "Conservation of Saker (Falco cherrug) in the Carpathian Basin" during the period 2006-2010 and by the LIFE-Nature project "Conservation of Falco cherrug in NE Bulgaria, Hungary, Romania and Slovakia" during the period 2010-2014. The project activities usually focused on EGS reintroduction programmes with the aim of ensuring the food base for selected species of birds in areas where EGS were the primary historical prey and have become extinct.

\section{Reintroduction programme}

There are several target sites where EGS colonies have been established within the LIFE and other projects during the last 11 years: Kuchyňa-Vývrat, Záhumenice (Kuchyňa), Breziny (Klátová Nová Ves), Biele Vody and Javorníková (Muráň). Detailed information about the methodology and results of reintroduction of EGS is summarized by Matejů et al. (2010). This article summarizes additional - unpublished information about EGS reintroduction and conservation results. Recently the reintroduction was carried out at two sites in Slovakia: Piesočná (cadastral area of Moravský Svätý Ján, west of Slovakia 48 $366^{\prime} 5.5099346^{\prime \prime}$ N, $16^{\circ} 57^{\prime}$ $12.7262878^{\prime \prime}$ E), Pod Okrúhlou skalou (cadastral area of Tisovec, middle of Slovakia, $48^{\circ} 40^{\prime} 17.1758285^{\prime \prime} \mathrm{N}$, $19^{\circ} 54^{\prime} 55.06073 "$ E). EGS were live-trapped by using cages and snares attached at burrow entrances at particular source sites. The source sites situated in the middle and east of Slovakia are (9): Gemerské Dechtáre, Jánovce, Jesenské, Muráň (Biele vody), Turňa nad Bodvou (Skalistý potok), Zádiel (Zemné hradisko) pastures; Košice, Spišská Nová Ves - airports; Moravský Svätý Ján (Piesočná) - mown meadow. At Košice airport the management of the area was not sufficient until 2012 and the population of EGS declined rapidly (only one male was captured there in 2013). The source sites situated in the west of Slovakia are (6): Chtelnica, Kuchyña - pastures, Bratislava, Trnava, Nové Zámky - airports and Bojnice Zoo.

Generally we can say that the choice of sites for capturing of the animals was influenced by bad conditions in colonies in 2012, caused by heavy rains and floods in 2010. Large airport areas were under water and population of EGS was declined. Permission for capturing individuals in the Slovakian Karst was not granted. The State Nature Conservation Office was worried about weakening of colony stability due to the capture. At Bojnice Zoo we were not able to capture squirrels due to construction work taking place around the aviaries in 2012. There were only 18 individuals captured there during the whole period of project duration.

Captured individuals were categorized according to sex and age: adults (males and females after first hibernation and older) and juveniles (males and females before first hibernation). Before releasing we cut part of the fur on the individuals back or head to recognize them through binocular observation or by using phototraps (Fig. 1).

Since 2013 microchips were also used, applied under the skin of animals. Each microchip has a serial identification number that can be read with a small portable reader during trap monitoring. Before this tagging method ear-tags were used, but then we realized that 


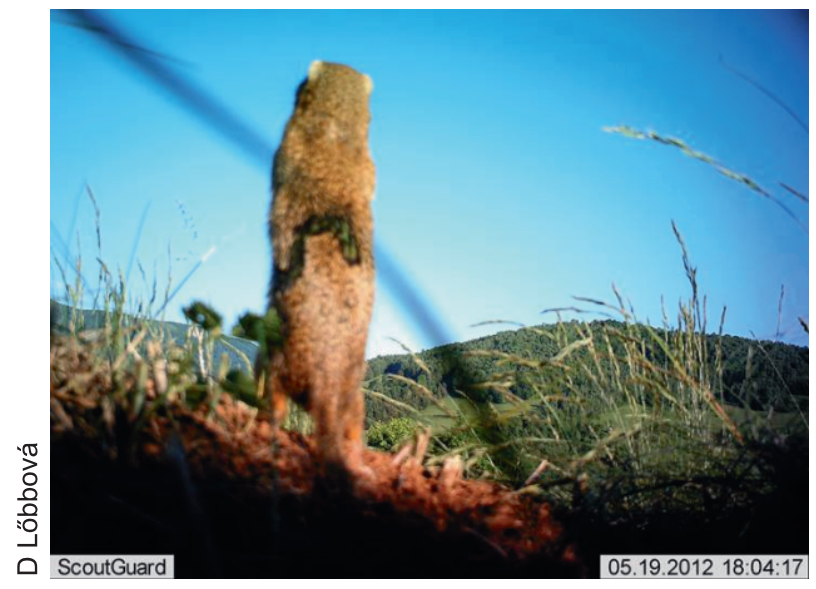

Fig. 1. Example of photo-trap picture demonstrating identitfication of an individual based on cut part of fur.

Obr. 1. Ukážka snímky z fotopasce znázorňujúca identifikáciu jedinca podla vystrihanej srsti.

after one active season the ear-tags usually dropped out and the ears of ground squirrels were hurt. During the reintroduction programme it was necessary to note all movements of released individuals (interactions, creating of new home ranges). Sociability and creating the new relationships between released individuals may play a main role in reintroduction success. We carried out squirrel monitoring at both sites to verify the success of colonization (visual observation of individuals, counting active burrows). The animals were fed additionally with barley, corn, sunflower seeds and some fruits like apples and cherries to improve their condition before hibernation.

\section{Monitoring and management}

The period that immediately follows after the releasing of individuals into a new area is usually very critical for the animals, because they have to build completely new secure burrows. It is necessary to check them almost nonstop for a few days (usually two days after releasing) and prevent predators occurrence. Monitoring of distribution, abundance, and quality of new burrows gives us an insight into the prosperity of the colony. The occurrence of extensive burrows is very important (i. e. those with large volumes of soil excavated, Fig. 2) and vertical burrows that indicate a complex underground system Altogether there were 174 individuals released at the Pod Okrúhlou skalou site, and 284 individuals at the Piesočná target site. Monitoring of both repatriated

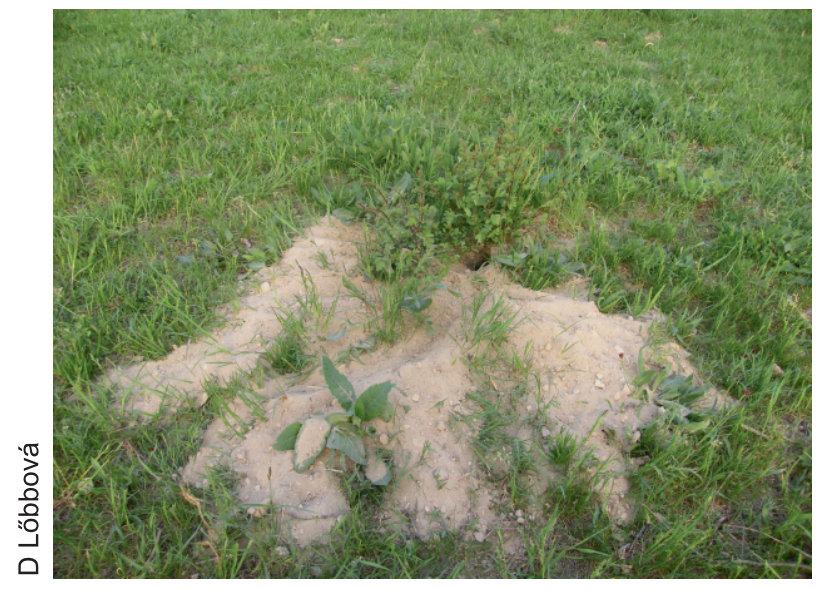

Fig. 2. Squirrel burrow with large volumes of soil excavated. Obr. 2. Šikmá nora sysl'a s nahromadenou pôdou po hrabaní.

colonies focused on the natality and distribution area.

Pod Okrúhlou skalou (Tisovec): The very first individuals that were captured for removal in order to create a new colony were found at Muráń (Biele vody) in 2011. The source colony was not weakened by this capturing, because we decided to take only some males which could prepare a new system of burrows for the next releasing. Eight males were released in the spring of 2011. Two days after releasing a number of these individuals were hunted down by a fox. Fig. 3 shows the distribution of burrows: the individuals occupied their new burrows in the area where they were released, and they created new burrows up to a distance of 30 meters away. Unfortunately no squirrel was observed during spring 2012. In this particular location another 19 males were released. Preventive measures were also taken against digging and enlarging the burrows by foxes, by laying large rocks around the burrow entrances. During the spring of 2012 until the next (summer) releasing, 28 active burrows were observed, and 9 of them were located in a mown meadow. This part of the area is not very good for EGS occupation, because of high cover level during the growing season (the grass is usually higher than $30 \mathrm{~cm}$ with addition of lucern). An interesting observation was again made during monitoring burrows from first releasing in 2011 (Fig. 4). During the summer of 201262 individuals were released. The stabilized colony actively used 34 burrows focused on the area from the first releasing in 2011 (Fig. 5). Successful 

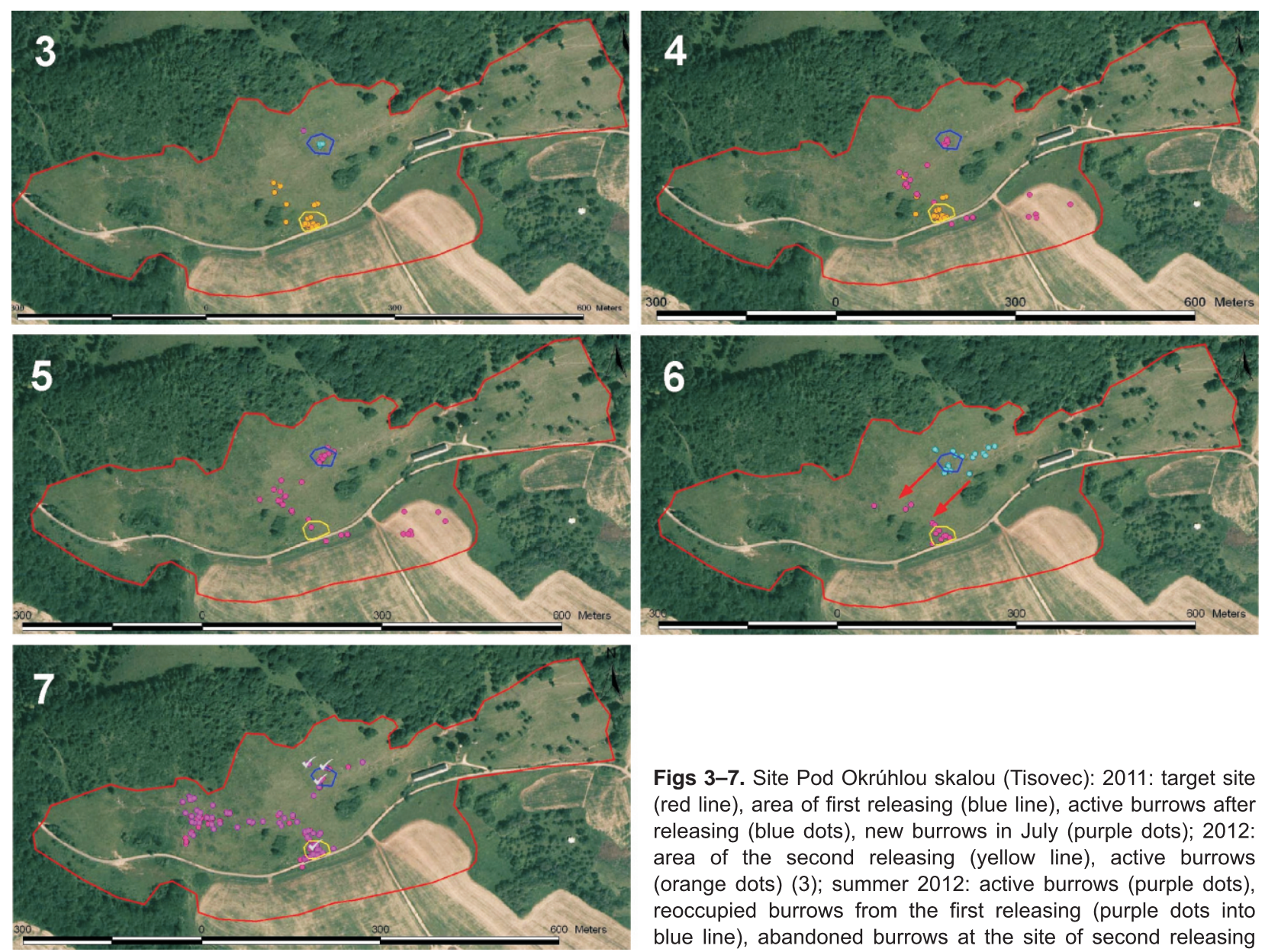

Figs 3-7. Site Pod Okrúhlou skalou (Tisovec): 2011: target site (red line), area of first releasing (blue line), active burrows after releasing (blue dots), new burrows in July (purple dots); 2012: area of the second releasing (yellow line), active burrows (orange dots) (3); summer 2012: active burrows (purple dots), reoccupied burrows from the first releasing (purple dots into blue line), abandoned burrows at the site of second releasing (orange dots into yellow line) (4); stabilization of active burrows before hibernating (purple dots); some active burrows are located in a less favourable meadow (5); 2013: transmigration

hibernation was observed with 31 active burrows during the spring of 2013. Unfortunately strong rainfall influenced the progress of the colony in May and June 2013 and its transmigration (Fig. 6). We think that the bad weather caused the loss of many animals and also no reproduction. It is possible that individuals created a new social structure due to transmigration in the west part of the project area, which is good for stability of the residual colony. This consideration was confirmed in spring 2014 when the colony began to thrive. A total of 76 active burrows were recorded in April, then 54 burrows in May, and a further 24 individuals were released (Fig 7). Rainy weather again endangered the success of reproduction. Nevertheless in June we observed 4 females with juveniles. The total number of juveniles was only $9(1 \times 1,2 \times 2,1 \times 4$ juveniles $)$. The pasture has to be maintained with additional management (cutting the grass with a brush-cutter), because inof colony after strong rainfalls, active burrows (purple dots), abandoned burrows (blue dots) (6); 2014: expansion of colony to new sites - result of reintroduction, active burrows (purple dots), maternal burrows (white check mark) (7).

Obr. 3-7. Pod Okrúhlou skalou (Tisovec): 2011: ciel'ové miesto (polygón vyznačený červenou čiarou), miesto prvého vypúštania (polygón vyznačený modrou čiarou), aktívne nory po vypúšt’aní (modré body), nové nory v júli (fialové body); 2012: miesto druhého vypúšt’ania (žltá čiara), aktívne nory (oranžové body) (3); leto 2012: aktívne nory (fialové body), opätovne obsadené nory, ktoré boli aktívne pri prvom vypúšt'aní (fialové body $v$ polygóne vyznačenom modrou čiarou), opustené nory $v$ mieste druhého vypúšt'ania (oranžové body $v$ polygóne vyznačenom žltou čiarou) (4); stabilizácia aktívnych nôr pred hibernáciou (fialové body), niektoré aktívne nory sa nachádzajú v nepriaznivej časti pasienku (5); 2013: emigrácia kolónie po silných dažd'och, aktívne nory (fialové body), opustené nory (modré body) (6); 2014: expanzia kolónie do nových častí pasienku - výsledok reštitúcie, aktívne nory (fialové body), materské nory (nory $s$ úspešnou reprodukciou, biely symbol zaškrtnutia) (7). 


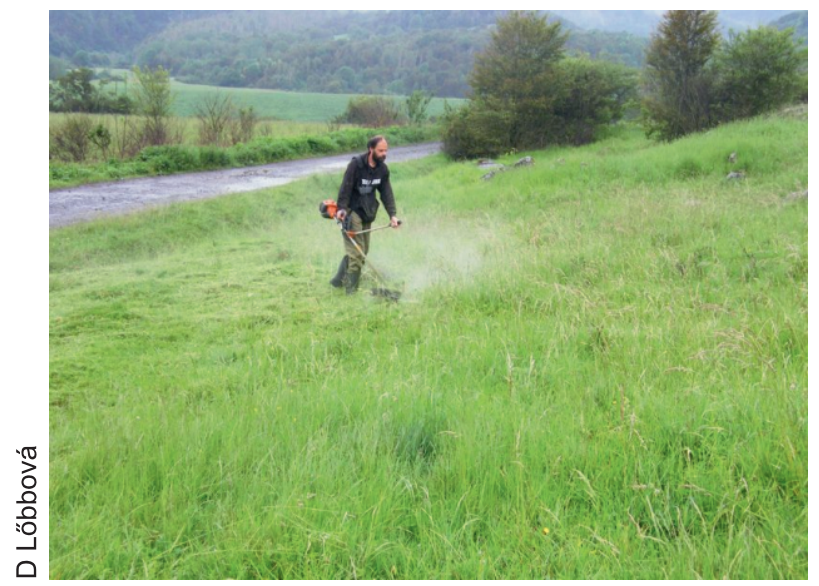

Fig. 8. Cutting grass with brush-cutter after rainy days; Tisovec. Obr. 8. Kosenie trávneho krytu krovinorezom po dažd’ových dňoch; Tisovec.

tensified grazing was not sufficient to create optimal conditions for the EGS population (Fig 8). Currently EGS occupy 1.9 hectares, which means approximately $10 \%$ of the project area.

Piesočná (Moravský Svätý Ján): We released 98 individuals during the first year of reintroduction in 2011. EGS occupied a new area but still used the releasing area (Fig 9). We had to eliminate the interest of predators for this site that represents a new potential food source by filling in the predators' lairs near the location area. It is very interesting that some squirrels occupied one of the old buried lairs of a fox. Successful hibernation was observed. The colony was stabilized with a sufficient number of individuals and good-quality burrows, and we were looking forward to successful reproduction. For this reason only 6 individuals were released there during the spring of 2012. However the colony declined rapidly and reproduction was not confirmed. The real reason for the decline was not detected. The colony increased after other individuals were released during the summer of 2012. A smaller number of squirrels than expected woke up from hibernation. We observed only a few active burrows, because the rainy spring in 2013 together with poor management of the project area caused total fading of the repatriated colony. The individuals released during the summer of 2013 found the old EGS burrows and occupied those (total 33 burrows). Reproduction was observed for the first time at this site in May 2014. One female captured at Bratislava airport, released on 3. 4. 2014 at the Piesočná site, had five young. Altogether 15 individuals were observed on this date. In May 2014 squirrels occupied about 70 burrows (including vertical holes, indicating good stability of underground systems; Fig 10).

\section{A s s o c i a t e d a c t i o n s}

Thanks to support from the Small Member project of
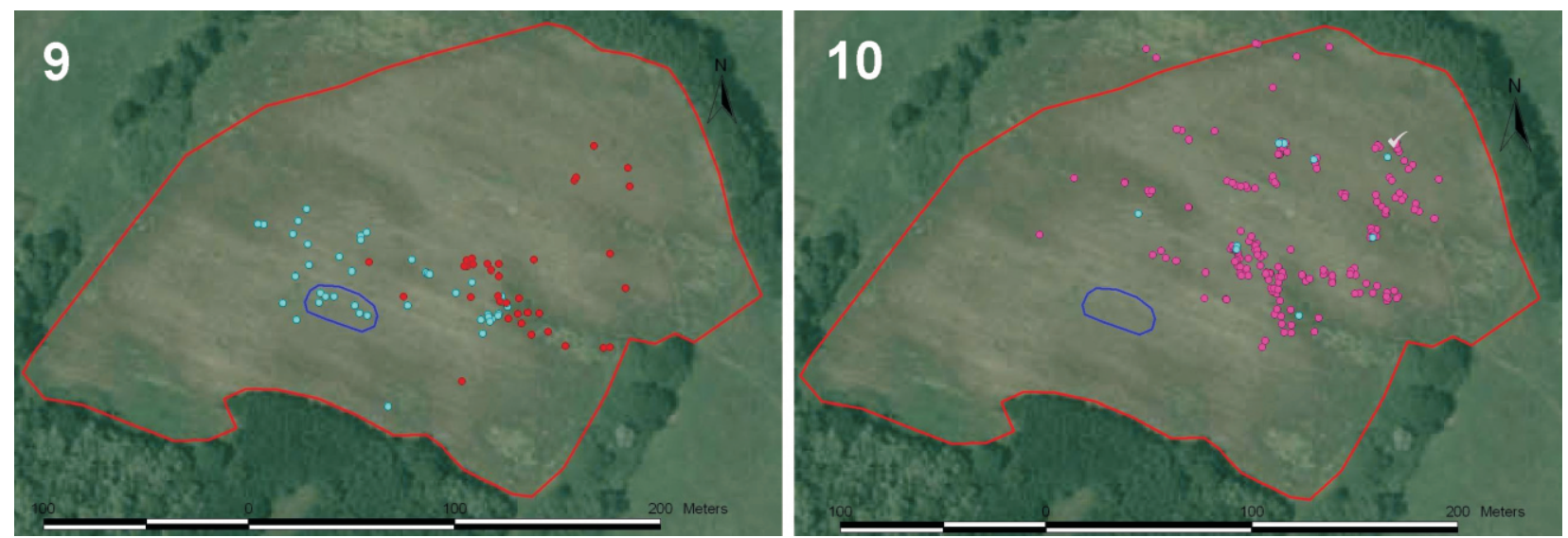

Figs 9-10. Site Piesočná (Moravský Svätý Ján): 2011: target site (red line), area of first releasing (blue line), active burrows (blue dots); 2012: active burrows (red dots), squirrels leaving area of first releasing (9); spring 2013: a few active burrows (blue dots), 2014: result of reintroduction: active burrows (purple dots), maternal burrow (white check mark) (10).

Obr. 9-10. Piesočná (Moravský Svätý Ján): 2011: miesto prvého vypúštłania (polygón vyznačený modrou čiarou), aktívne nory (modré body); 2012: aktívne nory (červené body), sysle opustili miesto prvého vypúšt’ania (9); jar 2013: málo aktívnych nôr (modré body), 2014: výsledok reštitúcie: aktívne nory (fialové body), materské nory (nory s úspešnou reprodukciou, biely symbol zaškrtnutia) (10). 
RPS, the activities of the previous LIFE projects continued in 2014. During this season management was applied at the Kuchyña-Vývrat target site. Bushes were trimmed, stones removed, the grass was cut and individuals were fed at this site covering about 10 hectares occupied by the colony. Currently there are intensive protection measures being implemented at Murán (Biele vody), and these have established the EGS population. Management of the area is maintained by keeping donkeys and by timing the mowing of the area during the most needed periods, i. e. when juveniles come out from maternal burrows. Squirrels are fed during the whole active season. With such intensive care the colony will possibly be able to grow at more than $50 \%$ per year.

\section{Conservation measures}

The a c tion pla $n$

EGS is a protected species (of European importance) according to Annexes $4 \mathrm{~b}$ and $6 \mathrm{~b}$ of Regulation $\mathrm{Nr}$. 24/2003 to Law No. 543/2002. In 2011, the Daphne/N2K Group started to prepare the Action Plan for the Conservation of the European ground squirrel (Spermophilus citellus) in the European Union. The Action Plan was approved by the European Commission in 2013. The main objective of the plan is to ensure the survival of the European ground squirrel as part of thecountryside.

\section{Th re a t s}

The critical threats are connected either with lack of grassland management, such as low (insufficient) intensity of grazing or mowing or the total absence of them. Other kinds of threats, connected especially with the reintroduction programme (creating a new colony), include the movement of dogs and cats at the target sites. The most important measure to solve this problem is to maintain low grass cover that can increase antipredator vigilance by individuals in the colony. Another example of the threat to some EGS colonies in Slovakia is the illegal trapping of animals and the use of chemicals for grassland treatment. EGS also disappear from those sites where mulching has started. Mulched sites become very wet and dense, and EGS cannot move as fast as usual and possibly they lose their interaction in the colony. High humidity also represents a threat to their lives.
Re i n t r o d u c t i o n n e w s

Currently the implementation of the reintroduction programme is a bit different and more sensitive in comparison to the actions included in the last methodological guide by Hapl et al. (2006). It accentuates vigilance regarding the number and sex structure of individuals aimed for releasing. From previous experience it is clear that a large number of individuals is necessary only when the care of the target site is not sufficiently ensured. The management of the site has to be perfect to enable the released squirrels to stay in contact with each other and to assign enough individuals to remain alert for predators. At the beginning (during the spring time) the first EGS burrows occurrence is important at the target site. For this intention the adult males could be released first, because their duty - mating - has already taken place in the source colony. During the summer the young could come into the prepared burrows. There is no reason to be wary of releasing more individuals into one burrow if it is sufficiently large. Gravid females could come into the prepared burrows during the spring over the next few years, in order to achieve birth of progeny at the target site. Source sites such as a small sports airfields open up suitable conditions for capturing the animals. The populations have huge densities in small areas (e. g. Nové Zámky airport). In most cases the individuals do not have the possibility to migrate. There are also no suitable sites for potential occupation by the species nearby.

\section{A 11 o c a t i o n}

On May 15 the Government of the Slovak Republic approved the draft Rural Development Programme for the period from 2014 to 2020, which will be the basis for the allocation of 2.079 billion EUR up to 2020. The draft was submitted to the European Commission in Brussels for approval, which is expected this autumn. One of the objectives of the programme is the sustainable management of natural resources, including biodiversity conservation. A new measure in the draft is intended to promote the protection of EGS habitats where the key conditions include prescribed grazing, mowing method and exclusion of chemicals (Nemcová 2014). From the perspective of the needs of EGS migration and settlement of new habitats there might be an interesting measure supporting the establishment of bio-corridors, or multifunctional edges of fields. These corridors with flowering plants and excluding chemicals are planned for 5000 hectares (lanes 5 meters $\times 1000 \mathrm{~km}$ ). 
P r e d a t o r s

At the Piesočná site mammalian predators are very common. Lairs of a badger and a fox have been found, but the main threat to EGS are wandering house cats. A local farmer captured 15 wandering house cats during one season (2014) surrounding the target site. With high probability this is the reason why we did not notice any increase in the colony in the period 2010-2013. Limestone grikes have helped to reduce the number of attacks by foxes at the Pod Okrúhlou skalou target site. Squirrels exploit the possibility to built their burrows beneath the grikes, and they preserve the burrows from predator destruction (Fig 11). Another positive issue here is the absence of wandering house cats.

F e e d i n g

During the period of 2002-2004 Matějů (2008) studied a $S$. citellus population inhabiting the golf range at Olšová Vrata, Czech Republic. He found that during hibernation the mortality of adult EGS reached $55 \%$ and that of juveniles as much as $90.6 \%$. He states that the high rate of mortality was probably caused by rapid snow melting and consequent flooding of the ground squirrel burrows. A similar population crash was described by Hoffmann et al. (2003) at a colony near Vienna, thus these events affecting EGS populations seem to be quite common. We think there is a potential chance to improve the fitness and health conditions of individuals by additional feeding at the target sites to reduce the percentage of EGS mortality (Fig 12). We usually use barleycorn and sunflower seeds because the other cereals such as rye or wheat can be poisonous for EGS or could cause diarrhoea in wet weather.

We a $\mathrm{th}$ e $\mathrm{r}$ c o n d i t i o n s

The period of the establishment of new colonies was accompanied by several rainy seasons. These weakened the overall functioning of the reintroduction. Rain also has a negative effect on natural populations, especially when meadows cannot manage to dry out because of the high cover level. So long as no similar period occurs in the coming years, the survival of EGS in Slovakia will then depend on the application of traditional farmingmethods.

\section{Conclusions}

The successful hibernation of EGS has been confirmed at both target sites. This is an important sign that indicates the suitability of the target sites and possibility of

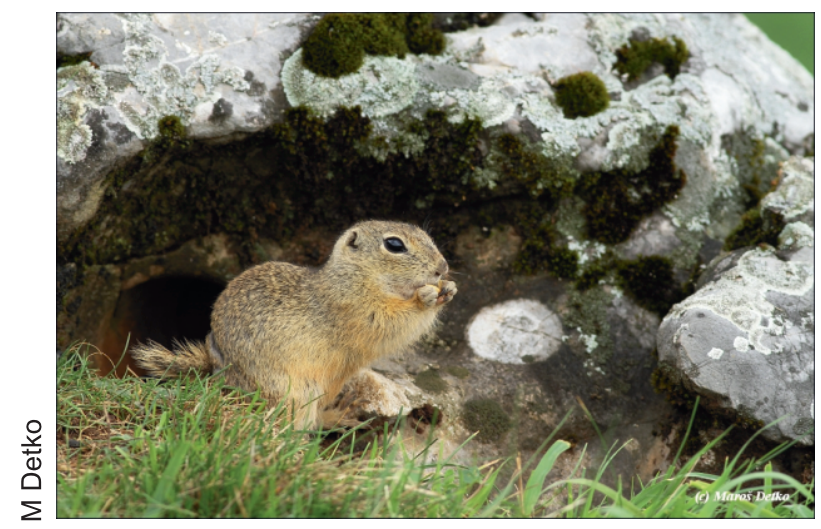

Fig. 11. Burrow entrance beneath grikes, Tisovec.

Obr. 11. Vchod do nory pod škrapom. Tisovec.

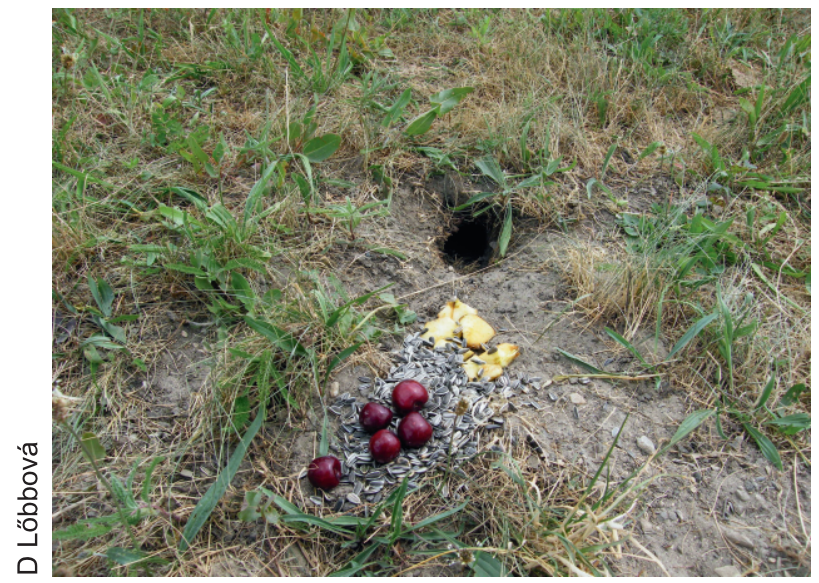

Fig. 12. Additional feeding of squirrels at target sites.

Obr. 12. Dokrmovanie sysl'ov na ciel'ových miestach.

EGS colony existence. Regular mapping and monitoring of the existing colonies is necessary for collecting information about the whole population and its prosperity. The main drawback of EGS protection in Slovakia is the lack of up-to-date knowledge about the occurrence of EGS populations and their current distribution. The status of individual sites is also unknown (abundance, density, threats like disappearance of colonies due to inappropriate management, migration barriers, genetic stability or sex ratio of colonies). It is necessary to start the implementation of separate measures of the new Action Plan in practice. The protection is poor, because Natura 2000 and national protection sites cover only small parts of the EGS population areas, most of them located within state or private grazing areas. Obtaining 
the financial support based on the Rural Development Programme is not an administratively simple process for farmers. We think that if the farmers had external consultants dealing specifically with the target species or working on projects aimed at the species, the number of applications for support could increase.

\section{References}

Ambros M 2008: Stav poznania rozšírenia sysl'a pasienkového (Spermophilus citellus) na Slovensku v rokoch 1996 až 2008 [Current knowledge on the distribution of the European Ground Squirrel (Spermophilus citellus) in Slovakia in 1996-2008]. Lynx, (Praha) 39: 219-233. [In Slovak with English summary]

Baláž I, Jančová A \& Ambros M 2008: Reštitúcia sysl’a pasienkového (Spermophilus citellus) na Slovensku [Restitution of the European Ground Squirrel (Spermophilus citellus) in Slovakia]. Lynx (Praha) 39(2): 235-240. [In Slovak with English summary]

Hapl E, Ambros M, Olekšák M \& Adamec M 2006: Reštitúcia sysl'a pasienkového (Spermophilus citel$l u s)$ v podmienkach Slovenska. Metodická príručka [Restitution of the European Ground Squirrel (Spermophilus citellus) in Slovak republic conditions Methodical quide]. Štátna ochrana prírody SR, Banská Bystrica, 40. [In Slovak]
Hoffmann IE, Millesi E, Huber S, Everts LG \& Dittami JP 2003: Population dynamics of European ground squirrels (Spermophilus citellus) in a suburban area. Journal of Mammalogy 84: 615-626.

Matějů J 2008: Ecology and space use in a relict population of the European Ground Squirrel (Spermophilus citellus) at the north-western edge of its distribution range. Lynx (Praha) 39: 263-276.

Matějů J, Říčanová Š, Ambros M, Kala B, Hapl E \& Matejů K 2010: Reintroduction of the European Ground Squirrel (Spermophilus citellus) in Central Europe (Rodenia: Sciuridae). Lynx (Praha) 41: 175-191.

Nemcová T 2014: Program rozvoja vidieka 2014-2020: nádej pre ohrozené vtáctvo polí a lesov? [Rural Development Programme 2014-2020: A chance for endangered birds of arable land and forests?] Vtáky 9 (2): 6-6. [In Slovak]

Uhlíková J, Matějů J, Nová P \& Vohralík V 2009: Sysel obecný - hlodavec, který nesyslí [The European Ground Squirrel - Rodent that don't victual himself]. Agentura ochrany prírody a krajiny České republiky, Praha, 16. [In Czech with English Summary] 